Meta

Journal des traducteurs

Translators' Journal

\title{
To Translate or not to Translate?
}

\section{Ashok R. Kelkar}

Volume 30, numéro 3, septembre 1985

URI : https://id.erudit.org/iderudit/003299ar

DOI : https://doi.org/10.7202/003299ar

Aller au sommaire du numéro

Éditeur(s)

Les Presses de l'Université de Montréal

ISSN

0026-0452 (imprimé)

1492-1421 (numérique)

Découvrir la revue

Citer cet article

Kelkar, A. R. (1985). To Translate or not to Translate? Meta, 30(3), 211-223.

https://doi.org/10.7202/003299ar

Ce document est protégé par la loi sur le droit d'auteur. L'utilisation des services d'Érudit (y compris la reproduction) est assujettie à sa politique d'utilisation que vous pouvez consulter en ligne.

https://apropos.erudit.org/fr/usagers/politique-dutilisation/
Cet article est diffusé et préservé par Érudit.

Érudit est un consortium interuniversitaire sans but lucratif composé de l'Université de Montréal, l'Université Laval et l'Université du Québec à Montréal. Il a pour mission la promotion et la valorisation de la recherche. https://www.erudit.org/fr/ 


\section{TO TRANSLATE OR NOT TO TRANSLATE?}

ASHOK R. KELKAR

\section{TRANSLATION IN PERSPECTIVE}

Competence in the use of language is communicative competence and so distinguished from formal competence (for example, the capacity to judge whether a sentence is grammatical or not). Communicative competence comprises reception, production, and reproduction, the last partaking a little of the other two. Competent reproduction implies competent reception of the original or model leading on to competent production of a replica. Like the other two skills, reproduction may operate either at the level of the signant (signifiant) or at the level of the signate (signifie). Just as reception may be either bare listening (or reading) or the same with comprehension, reproduction may be either bare repetition (i.e. re-rendition confined to the level of auditory or visual signals) or reexpression (i.e. re-formulation at the level of form and meaning as well). Paraphrase from formal to colloquial, for example, is reformulation within the same language. Translation, on the other hand, if reformulation across languages, at least across dialects of the same language. It can therefore be defined as the reformulation of a text in some linguistic code (the source text in the source language or dialect) into a replica text in another linguistic code (target language or dialect).

The involvement in this kind of reproduction of two languages or dialects - two linguistic codes - creates a complication. So long as we are not aware of this complication we think of translation simply as removal of one set of clothes and putting on another set of clothes to cover the same meaning - French cheval goes to English horse but chien goes to dog, or vice versa. This simple (and simple-minded) scheme can be presented as follows :

(2) Form-S

\section{Form-T}

Here the symbols S and T are shorthand for "in the Source text" and "in the Target text (replica)" respectively. Now, while such a scheme may do some justice to intra-language reformulation (e.g. paraphrase), it hardly does any justice to inter-language reformulation, i.e. translation. To realize this is to realize that translation is a difficult job full of compromises and thus say despairingly with Italians, Translators are traitors ! Rather than giving up translation as an impossibility, we should give up our too simple scheme. A more realistic scheme will be as follows :

(3) Form-S $\longrightarrow$ Meaning-S

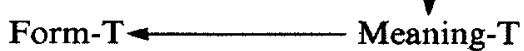

In translating we are not merely matching forms in the two languages in respect of meanings ; we are also matching meanings as well in the two languages. What are distinct meanings in one language often turn up as a single merged meaning in another we drink water, eat bread, and smoke cigarettes in English, in Bangla all three verbs 
translate as $k h a \bar{a}$ (etymologically, ' eat'). This does not mean that Bangla speakers ' eat' their water or cigarettes, rather it is simply that $k h \bar{a}$ in modern Bangla corresponds to English consume. Meanings are rearranged - English he is hungry comes out as il a faim (he has hunger) in French, he has cold feet as il a froid aux pieds (he has cold in the feet). The Marathi question tyā rāngetla kitva ghar (that row-in how-many-eth house ?) can be translated into English or French only in a very roundabout manner. The category jūthan in Hindi can be easily matched in Marathi (that which has been tasted by one person and thus rendered unfit for another's consumption by virtue of a taboo said of a portion of food or drink and, by extension, said of spoons, cups, mouth-pieces of musical intruments, and the like) but not in English or French - the leap across meanings (from Meaning-S to Meaning-T) may also turn out to be a leap across cultures. Finally, translators can choose to be more ambitious ; they may attempt to bridge the gap between forms as well. Between closely resembling languages like Hindi and Urdu, translation is often no more than a change of script (or speech accent); even at its most difficult, it is only a morpheme-by-morpheme replacement. Translating a sentence in British English into American English is often indistinguishable from repeating it with sound-by-sound replacement. But, loosely speaking, the language gap can be bridged even when the languages do not resemble each other so closely. The French cela $v a$ sans dire is matched by the English Gallicism that goes without saying. (The French call this process a calque.) Schematically, we can symbolize this bridging over as follows :

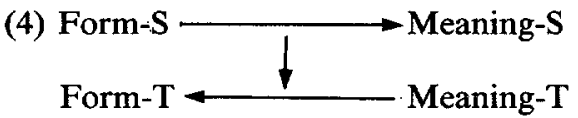

Translations that attempt to graduate from (3) to (4) more or less successfully can be termed close translation; those that do not may be termed distant translations .

By now it should be abundantly clear that an original in one language may be translated in more than one manner in another language; that a translation cannot achieve everything - it can achieve one thing usually by sacrificing another ; and that one translation can be said to be better or worse than another only in respect of what we expect the translation to achieve. If we should translate "His eyes are blue" to Il a les yeux bleus (he has the eyes blue) in French, we are guilty of rearranging the meaning but we are to be given credit for idiomatic, natural French. On the other hand, if we select Ses yeux sont bleus, we are more faithful to be English arrangement but less elegant in French. No wonder that the translator's predicament was likened by Voltaire to the prospective husband's. Translations, like wives, can be either faithful or beautiful, but not both!

The important question, then, is, what do we expect a translation to accomplish ? Translations can give more weight to the exercise of receptive competence (decoding) or to the exercise of productive competence (encoding). We have already pointed out the essentially two-sided nature of reproductive skills. Given the original text in the source language, to offer a translation of it in the target language is to offer an answer to either of the two following questions :

(5) (i) What does the original text say? (The answer being a decoding translation, a gloss, so to say.)

(ii) How can one say the same thing in the target language? (The answer being a reencoding translation, a counterpart or equivalent, so to say.)

A translation of the first sort does not care too much for acceptability in the target language (Ses yeux sont bleus is good enough). To say that a given translation does not 
read like a translation at all is appropriate praise only in respect of the second sort. "My mother's brother is here" offers a better decoding of the Marathi sentence containing māmā, but "My uncle is here" is a version that is more nearly English. ("Mother's brother, do take me with you !" is indeed impossible as a reencoding.) Similarly, while consume may be a perfect gloss for Bangla $k h \bar{a}$, we'll have to think of eat, drink, smoke as its ready equivalents.

One must not confuse this distinction between decoding and encoding translations and the other distinction, established earlier, between close and distant translations. A decoding translation may be close or distant ; and a reencoding translation may also be close or distant. Theoretically, there are four possibilities in all. A decoding translation is primarily faithful to the source text. A reencoding translation is primarily faithful to the target language. A close translation seeks to be faithful to the grammatical and possibly phonological form of the text as well - typically, it achieves this by choosing a smaller unit for processing, say, a word rather than a sentence, a line rather than a stanza. A distant translation is content to take care of meaning and leave form to take care of itself.

The everyday terminology of free rendering and faithful rendering is lax in that "faithful" tends to mean close or decoding or both and "free" tends to mean distant or reencoding or both. This everyday terminology probably goes back historically to the main arenas of European translation activity - the translation of the Bible by the faithful for the faithful that began with the Reformation and the translation of the Greek and Latin classics that began with the Renascence. The two are set up as ideal types by Goethe and, later, by Friedrich Schleiermacher, both good translators. Says Goethe in the eulogy of Wieland :

There are two maxims for translators; one demands that the author belonging to some other nation should be brought over to us, so that we can regard him as our own [cf. reencoding] ; the other demands of us that we should go across to the stranger [cf. decoding] and accustom ourselves to his circumstances, his manner of speaking, his peculiarities [cf. closeness].

\section{Schleiermacher's formulation is an improvement :}

A translator either leaves the author as much alone as is possible [cf. decoding] and moves the reader towards him [cf. closeness] ; or he leaves the reader as much alone as is possible [cf. reencoding] and moves the author towards him [cf. distantness] ${ }^{1}$.

\section{TRANSLATION OF LITERATURE}

The translation of literary texts is translation at its most challenging; for a literary text is produced as well as received in a more complex manner. So the leap from Meaning-S to Meaning- $T$ is correspondingly more difficult.

In the first place, style in its broadest sense mediates between the linguistic text comprising Form and its Meaning on the one hand and the work of literay art looming behind it on the other. From the producer's point of view, style is finding the right means for the communicative end in view. From the receiver's point of view, on the other hand, to become aware of style is to trace the enjoyment, the feel of the text to the way the text is formed. Each language has its own norm or norms of style. In Victorian English the stylistic norm required that men sweated and ladies perspired! Between French and English thresholds that decide what constitutes an overstatement or an understatement differ noticeably. An Englishman who is unaware of this difference will take a Frenchman's Je suis enchanté (I am enchanted - to see you) too seriously; a Frenchman who doesn't know of the Englishman's tendency to understatement will be 
put off by the latter's not too bad. (In American English, not too bad may of course translate as fantastic or super!) Languages may also differ as to what is regarded as language appropriate to literature and on how far this language differs from everyday language. Thus poetry in Modern Indian languages tends to depart from ordinary language much more than poetry in contemporary English does. A good literary translation has to translate meaning in its entirety and the meaning of the source text in its entirety includes the style of the source text.

It might be objected that what has just been said about style and its relation to translation points to a problem that is not peculiar to the translation of literature as such. All literary texts are stylized, but not all stylized or crafted texts are literay works of art. The objection would be a valid one in that something more is involved in literary translation than leaping across the stylistic gap between the source language and the target language. We have to point out, first, that poetry is fundamentally untranslatable and, secondly, that all literature aspires towards this condition of poetry. To get at the root of this problem let us follow Punya Sloka Ray's attempts to get at The Formation of Prose (1962a : 313) :

Let us begin with a dilemma. Language is impossible if the speaker and hearer do not agree at all on what forms should carry what meanings. And yet, language is useless if the speaker and the hearer could agree completely without recourse to the meaningful forms between them. So language is usable only insofar as we do not depend upon it, and yet language is useful only insofar as we do depend upon it. Fortunately, the absoluteness of the paradox is only a metaphysical make-believe... But this formulation does serve to highlight a certain duality in our handling of language - the systematic cultivation of dependence on language will be defined as poetry and the systematic cultivation of independence from language defined as prose - prose we shall define as a movement away from poetry.

One can now begin to understand why one finds it difficult if not impossible to translate poetry. In poetic style, finding the right means for the communicative end in view cannot be seperated from having a certain communicative end in view ; nor can understanding the enjoyment, determining the feel of the text be separated from tracing the way the text is formed. The success of prose (and Punya Sloka Ray has primarily utilitarian prose in mind in the discussion quoted from) depends precisely on the separation of the Form and the Meaning of the text. (After all, that is precisely what a technical vocabulary is trying to accomplish.) The artistic success of poetry and of a good deal of literay prose depends on the integration of Form into Meaning. That is why poetry most resists both paraphrase and translation. A poem can only bear repetition.

This leads us to the next step in our argument. Translation of a literary text is no mere exercise in the reproduction of the original text. Rather, literary translation is the recreation of the whole original communicative transaction itself, inclusive of the original text. The result is a fresh communicative transaction, namely, the production and reception of the replica text. The translator's job here is more akin to the job of the stage team producing a play - both are acts of interpretation. The translator of a literary work has the same privilege of expecting his reader to rise to the occasion as the original artist has. What is more, the demand made on the reader of a translation is always going to exceed the demand made on the reader of the original text.

Earlier we set up a scheme of four modalities of translation.

(i) Decoding translation - which may range from very close to quite distant.

(ii) Reencoding translation - which may range from very close to quite distant. 
An example is in order - the opening line of Goethe's well-known poem about Italy (Wilhelm Meisters Lehrjahre 3:1) will serve our purpose :

(7) Source text in German :

Kennst du das Land, wo die Zitronen blïhn?

Target replicas in English :

(i) Do you know the country where the lemontrees bloom?

(ii) Say, you know the land of the lemon-trees in bloom?

(iii) Knowest thou the land where the lemons bloom?

(iv) Know you the land of lemon blooms?

The first two versions tell us in plain English what the source text says - incidentally the source text also says it in plain German. These two are decoding translations. The other two versions, being reencoding translations, seek to provide us with poetic equivalents of the original ; (iii) does it more closely in terms of the rhythm and the word frame; both choose land though land is not the commonest choice in English in this sense (country is a nearer gloss) because it preserves the rhythm and the tone. Just as (iv) is more distant than (iii), (ii) is more distant than (i). Note that while thou for you and question by simple inversion without a supporting do are specifically archaic and poetic in English, the corresponding choices in German do not carry any such qualifications. To this extent (iii) and (iv) deviate from the goal of stylistic equivalence, but thereby gain through the retention of the rhythm and the tone.

Though all the four modalities can thus be attested, the fact remains that the closer translation lends itself better to decoding and the more distant translation to reencoding. This is presumably because differences of Form (on which the close/distant distinction hinges) and differences of Meaning (as handled by a decoding/reencoding replica) are more closely intermeshed than a simpler notion of Meaning (seen in (3) above) would lead us to believe to be the case. If we were to set a parallel scheme of distinguishing between four modalities for intra-language reformulation (e.g. paraphrase), it might turn out to be rather difficult to differentiate distant decoding from distant reencoding and close reencoding from close decoding in applying the classification to paraphrases and the like.

Dryden's celebrated distinction (1680) between the three heads of translation can be better understood in the terms proposed here. Dryden, it will be recalled, speaks of :

(i) the "metaphrase, or turning an author word by word, and line by line, from one language into another" ; (ii) the middle way, the "paraphrase, or translation whith latitude, where the author is kept in view by the translator, so as never to be lost, but his words are not so strictly followed as his sense ; and that too is admitted to be amplified, but not altered" ; (iii) the "limitation, where the translator (if now he has not lost his name) assumes the liberty not only to vary from the words and sense, but to forsake them both as he sees occasion; and taking only some general hints from the original, to run division on the groundwork, as he pleases."

In our words, Dryden's recommendation in favour of the paraphrase is recommendation for the via media of close reencoding between close decoding (his metaphrase) and distant reencoding (his imitation). The Nineteenth Century historicist scruples came to favour closeness to distantness, while the Romantic conception of the relation between poetry and language came to favour reencoding to decoding 2 .

Whichever modality we select in translating a literary work of art, the full spectrum of meaning needs to be attented to. Assessing the meaning or value of an expression is not merely a question of assessing (a) the range of application (thus, both Hindi 
icchä-patr and Marathi mruttyu-patr are coterminous with will and testament in English) and (b) the defining, the diagnostic, and the associated features (thus, Zitrone and lemon are both to be defined as tree names as well as fruit names; Hindi iccha-patr and English will both single out the same feature 'wish' for attention, while Marathi mrutyu-patr associates the document with 'death'; while it is perfectly in order to speak of 'a male nurse', the mention of 'a nurse' without qualification leads us to expect a female by virtue of association). Meaning is something more : it is also a question of assessing (c) the associated expressions in the language and (d) the habitual situational contexts. To illustrate (c), English head and heart alliterate as well as oppose each other ; the collocations of German Land sometimes match with those of country in English.

Stadt und Land / town and country

Ausland / foreign country

die sïdlichen Länder / the southern countries

and sometimes match with those of land in English :

Landschaft / landscape

gelobtes Land / land of promise

Land der Träume / land of dream

(The example is from Forster 1958.) Turning to (d), we may notice that, where German will speak of Schlaflosigkeit and French of insomnie, English will tend to reserve insomnia for medical contexts and use sleeplessness as an everyday term. The first is a complaint, the second a condition or state. To sum up :

(8) The Meaning of a Form comprises :

(a) the range of application (Reference),

(b) the defining, the diagnostic, and the associated features (Sense),

(c) the range of associated expressions (Linguistic Context), and

(d) the range of habitual situational contexts (Pragmatic Context) .

One need not assume that a literary text always calls for a reencoding translation or that a close decoding translation is merely a scholar's tool for grappling with an obscure or unfamiliar text. The needs may also differ from one literay text to another. Just as a dramatist sometimes leaves some response on the part of the character without any verbal expression so that the stage actor has full scope for his own interpretation, some texts give full play to the reader's sensibility. A case in point will be a poem with strong visual imagery. Such texts lend themselves to a close decoding translation, so that the reader of the translation may enjoy the same freedom as the reader of the original. Such texts will often come through even in the a pedestrian or a casual translation. Take care of the images and the poetic reverberations will take care of themselves.

If the source text has an ambiguous or a condensed expression, a close translation will seek to match it with ambiguity or condensation rather than impose a resolution on the reader of the replica text. After all didn't the reader of the source text enjoy the freedom of either retaining or resolving the ambiguity and of either maintaining or elaborating the condensation? True, the target language may not always permit a choice to the translator in this matter. French familier de and English familiar with are both ambiguous between the sense 'sustaining informal relations as within a family' and the sense ' closely acquainted as with a member of one's own family', but German forces us to choose between vertrautlich mit and wohlbekannt mit (the cognate familiär being much less commonly used). Again, French une robe de soie, English a silk dress, German ein seiden Kleid are about equally elaborate in not using a single word or equally condensed in not explicitly saying that the dress is made out of silk (cf. a silkworm, but French un 
doigt de la main and un doigt du pied are certainly more elaborate than the English finger and toe respectively.

If the original presents an image as a symbol with an open-ended meaning or a detail full of associations in that culture, one can argue that a straight decoding translation is better even if it does not customarily arouse the associations in the target language and the associated culture. The very effort that the reader will have to make in order to meet the alien culture half way will be a reward. Certainly the effort to make things acceptable and familiar to the target language reader may be carried too far, and thus defeat the whole point of making an alien literature accessible through translation namely, a sharpening and broadening of sensibility, a gaining of the capacity to get more out of what one reads and to get along with a greater variety of reading matter ${ }^{3}$.

TRANSLATION OF NON-LITERARY DISCOURSE : AN ASIDE

Technical discourse stands at the opposite pole from literature in that it does not call for faithfulness to the form of the source text, but only to its message. A distant decoding should be enough. Translating English nitrogen (generated from nitre) as azote (not capable of sustaining life) in French makes no difference at all ; in either case the reference is to the element with the atomic number 7 . For other utilitarian prose such as advertisement, propaganda, practical instructions, tourist information, and the like effectiveness in the target language setting is all important. A distant reencoding will serve best.

Humanistic discourse lies halfway between literature and technical discourse. Cases in point are history (when it is not mere chronicle), philosophy (when it is not mere logic), the human sciences (when they are not mere natural history of Homo sapiens), literary criticism (when it is not mere factual literary scholarship). Translations in these areas will tend to waver between close decoding and close reencoding. Translating the classics in these areas will favour the former ; translating works on live issues will favour the latter. (As for mere chronicle, mere logic, mere natural history of man, and mere literary scholarship, a distant decoding should be enough for translating such material.)

\section{A CASE STUDY : BAUDELAIRE'S CORRESPONDANCES IN ENGLISH}

Let us look at some available English renderings of a celebrated French poem, Baudelaire's Correspondances (1857). The original French text and the texts of five renderings are reproduced in the Annexe for convenience. They will be referred to by the symbols $\mathrm{O}, \mathrm{A}, \mathrm{B}$. C, D, and $\mathrm{E}$. The renderings are respectively by

(A) Henry Peyre (1960)

(B) Kate Flores (1958)

(C) George Dillon (1936)

(D) Jacques Leclerq (1958)

(E) C.F. MacIntyre (1947)

Charles Baudelaire is of course a nineteenth-century (1821-1867) poet, critic, and moralist from France, who anticipated the Symbolist poets in technique and a good deal of modern poetry in spirit and his poem is a sonnet (the 14 lines rhyming abba, cdde, efe, fgg) in what is the staple form of traditional French verse ( 12 syllables, not counting the final mute syllable of a feminine rhyme, rhymes $b, c, f$ happening to be feminine).

Version A is by a French-born American critic and teacher of literature. There is no attempt at verse ; the translation is line-bound, however ; the units of translating are the word and the phrase. Like the other versions B, C, E, it appears in a collection presenting the original texts as well. Version $A$ is embedded in a commentary on the original. 
Version $B$ is by an American. It is in free verse, 14 lines averaging 4 beats; the translation is line-bound; the units of translation are the phrase and the clause.

Version $\mathrm{C}$ is by an American lyric poet. It is a sonnet, 14 lines of 12 syllables and 6 beats each, rhyming abba, cddc, efg, efg. (The English staple line is of course one of 10 syllables, 5 beats, rising rhythm.) The translation is bound by the 'stanza' (the two quatrains and the two tercets) ; the units of translation are the phrase and the line. (The line of the original is not always respected - consider mingling in line 5, springs in line 9, As prairies in line 11.) Edna St. Vincent Millay's "Introduction" to the collection (section II, end) clearly warns "the reader - who does not know much French, and who wishes to brush up on his French by comparing the original with the translation" that he "will possibly find himself after the study of a few phrases puzzled if not definitely embarrassed".

Version D appears in a collection composed exclusively of English translations. It is metrical : a sonnet, 14 lines of 10 syllables and 5 beats each, in rising rhythm. The rhyme scheme is abba, cddc, efefgg. The translation is line-bound; the units of translation are the phrase and the clause.

Version $\mathrm{E}$ is in free verse, 14 lines averaging 5 beats, the rhymes, which pattern as abba, cdcd, eef, gfg, are loose. The translation is bound by the 'stanza'; the units of translation are the phrase and the line (with the exception of familiar in line 3).

If we now apply the parameter of close/distant, versions A, D, B, E, C are, broadly speaking, in a descending order of closeness. While $\mathrm{A}$ is a frankly decoding translation, versions B, C, and E seem to claim some standing in their own right - as reencodings. Version $\mathrm{D}$ is again a decoding translation. The translator's remarks in the "Foreword" confirm this :

Over the years Baudelaire has enjoyed the honours of translation by poets who often produced exquisite lyrics in their own right. Yet it seems to me, not unwisely I hope, that there is a place for renderings closer to the original meaning, and, especially, to the original syntax, vocabulary and versification.

It will be seen that in a way all the four modalities we set up are exemplified here - the decodings range from very close (A) to not so close (D); the reencodings range from fairly close (B) to rather distant (E, C).

Lines O 1-8 have a majestic movement with deep pauses (in 1 after temple, in 4 after observent), heavy syllables (tonic long vowel or tonic vowel followed by consonant cluster), rounded vowels in tonic positions (vowels with what phoneticians call a grave quality). Lines 0 9-14 on the other hand have a lighter movement with shallow pauses (enumerative pauses in 11,13 ). B 5-8 and 9,10,12 succeed in capturing this. $\mathrm{C}$ has a verse line that is (for English) longer than usual ; C 6-7 and 12 capture the effect. D and $\mathrm{E}$ are adequate, but not especially close to the original in verse movement.

Lines O 1-2 have a peculiar French construction : columns allow words to escape (compare A 1-2). Versions B, E handle this by shifting the nouns around : voices or words emerge from the columns ; $C$ introduces seem - "pillars seem ... to babble ... words" ; $D$ lets the pillars speak words. The alternative adopted by $C$ is possibly better in that it maintains the 'animateness' of vivants piliers without overshooting the limit set by laissent sortir (as D does). The pillars are ' animated' but not 'personified'.

There is a grammatical problem in $\mathrm{O} 6$ une ténébreuse et profonde unité with its striking (for French) placement of two heavy adjectives before the crucial noun resulting in its suspense-building end-placement. A 6 has it word by word - $a$ shadowy and profound unity. B 6 has harmonies darksome and profound with 'Noun (Adj and Adj)' which is striking for English though superficially different from the French (ADJ AND 
ADJ) NOUN. E 6 proceeds on similar reencoding lines except that it retains unité unlike B 6. C 6 is even better - in one profound and cryptic whole unite deviates from the normal order, namely, 'Verb in one (Adj and Adj) N', but retains unité and its endposition. The reversal of the two adjectives in C 6 (profound before cryptic) is a concession to the rhythm (see earlier comment on C 6-7). D 6 In unity, in a deep darksome way is the weakest rendering as it dissipates the energy through the repetition of in and the divisive comma after unity.

Certain words in the original present interesting problems - parfums (in $\mathrm{O} 8$ and again in $\mathrm{O} 9$ ), chairs d'enfants $(\mathrm{O} 9)$, and triomphants (O 11). In the first case $\mathrm{A}$ and $\mathrm{E}$ simply use perfumes (which in English is much narrower in range - bottled liquids rather than the French parfums). Version B uses scents (8) where it is coupled with colors and sounds in general terms, but switches on to fragrances (9) to indicate one kind of scents also achieving the consonantal effect $(f r . . . f r . . . f)$. Version $C$ retains perfumes in both slots $(8,9)$, but throws in fragrances as a recapitulative noun later (10). Oddly enough, D reverses the choice - perfumes in 8 and scents in 9. French chairs and English flesh (A 9, B 9, D 9, E 9) exemplify here the sense seen in collocations like I saw him in the flesh, flesh-coloured stockings. C uses children's bodies (9) without losing the sense and the plural number, and also without bringing in unwanted images (flesh and blood, flesh or fowl). French triomphant, like English triumphant (A 11, D 11, E 11), can mean either decisively victorious or exulting as in a decisive victory. Versions B (overpowering, 11) and $C$ (proud, 11) have pinned down the first and the second of these senses respectively. the context $(\mathrm{O} 11)$ in the original has room for both of these senses - including the slightly vicious air associated with exulting over a fallen enemy.

Crucial to the success of a literay recreation is success in recreating images. Lines O 3-4 strikingly contrast the unobservant man with the oberservant, beckoning objects surrounding him with an uncanny reversal of rôles; the phrase regards familiers conveys intimacy, unabashedness, and usualness. (Recall the earlier comments on familier and familiar.) The eeriness of the situation is underlined by the choice of eyes in B 4, C 4, D 4, E 4 for the less concrete regards (cf. glances in A 4). But C goes further by adding peep and gleam (C 4) to the eyes and aware to the man (aware of eyes, 4). This is certainly not faithful to the text and points to a much bolder interpretation than the one suggested by the cautious seem at B 4 (compare the seem of C 1 commented on earlier).

Line $\mathrm{O} 13$ recalls a series of redolent organic substances - amber, musk, benzoin, and frankincense (A 13, Hindi ambar, mushk, lobānjāvi and lobān; the myrrh added by B 13 being hirābol). B drops musk and adds myrrh, while $\mathrm{C}$ describes benzoin and frankincense as burning spice or resin (13), a partial elaboration. This last illustrates the device of building the annotation into the replica text rather than awkwardly consigning it to the footnote.

Comparing the five English versions, which illustrate all the four modalities, one can see their differing goals and successes. Version $A$ is very modest in its aim and quite willing to serve the reader who would "brush up on his French" : it is no more than an extended running annotation in English (it even provides occasional alternatives in parentheses) to accompany the original French text. At the other extreme versions $E$ and $\mathrm{C}$ are frankly poems in English, differing only in the liberties taken with the formal aspect of the original. Versions D and B strike a middle path in their different ways, D less successfully so.

Together the five versions reflect the basic predicament haunting the would-be translator of poetry - to translate or not to translate. 


\section{ANNEXE}

The Sources of the Texts :

O Baudelaire, Charles (1857) : les Fleurs du mal, Paris.

A Peyre, Henri (1964). In : Burnshaw, Stanley (Ed., Introd.), The Poem Itself, [Collection of French, German, etc. poems, translations, and comments thereon.] New York, Holt, Rinehart and Winston. Also rptd., paperback, Pelican Book, Harmondsworth Middlesex, England, Penguin.

B Kate, Flores (1958). In : Flores, Angel (Ed.) : An Anthology of French Poetry from Nerval to Valéry in English Translation, Anchor Books, Garden City, N.Y., Doubleday.

C Dillon, George (1936). In : Baudelaire, Charles : Flowers of Evil. Translated by Dillon, George ; Millay, Edna St. Vincent. Introduced by Millay, Edna St. Vincent. New York.

D Leclerq, Jacques (1958). In : Baudelaire, Charles : Flowers of Evil. Translated by Leclerq, Jacques and illustrated by Hill, Jeff. Mount Vernon, N.Y., Peter Pauper Press.

E MacIntyre, C.F. (1947). In : Baudelaire, Charles : One Hundred Poems from les Fleurs du mal. Translated by MacIntyre, C.F., Berkeley, Los Angeles, University of California Press (The titles are left untranslated.)

The Texts :

O The Original Text by Charles Baudelaire (1857)

Correspondances

La nature est un temple où de vivants piliers

Laissent parfois sortir de confuses paroles;

L'homme y passe à travers des forêts de symboles

4 Qui l'observent avec des regards familiers.

Comme de longs échos qui de loin se confondent Dans une ténébreuse et profonde unité,

Vaste comme la nuit et comme la clarté,

8 Les parfums, les couleurs et les sons se répondent.

Il est des parfums frais comme des chairs d'enfants,

Doux comme les hautbois, verts comme les prairies,

- Et d'autres, corrompus, riches et triomphants

12 Ayant l'expansion des choses infinies,

Comme l'ambre, le musc, le benjoin et l'encens,

Qui chantent les transports de l'esprit et des sens

\section{A Henri Peyre (1960)}

Correspondences

Nature is a temple where living colums

Sometimes murmur indirect words (allow confused words to escape);

There man passes through forests of symbols

4 That watch him with familiar glances. 
Like prolonged echoes that mingle in the distance,

In a shadowy and profound unity,

Vast as night and as the light of day,

8 Perfumes, colors, and sounds respond to (answer to) one another.

There are perfumes, fresh as the flesh of children,

Sweet as oboe music, green as meadows,

- Others [are] corrupt, rich, and triumphant,

12 Having the expansion of things infinite,

Like amber, musk, benzoin, and frenkincense,

Which sing the raptures of spirit and of sense.

\section{B Kate Flores (1958)}

Correspondences

Nature is a temple from whose living columns

Commingling voices emerge at times ;

Here man wanders through forests of symbols

4 Which seem to observe him with familiar eyes

Like long-drawn echoes afar converging

In harmonies darksome and profound

Vast as the night and vast as light,

8 Colors, scents and sounds correspond.

There are fragrances fresh as the flesh of children,

Sweet as the oboe, green as the prairie,

- And other overpowering, rich and corrupt.

12 Possessing the pervasiveness of everlasting things,

Like Benjamin, frankincense, amber, myrrh,

Which the raptures of the senses and the spirit sing.

\section{George Dillon (1936)}

Correspondences

All nature is a temple whose living pillars seem

At times to babble confused words, half understood,

Men journey there through an obscure symbolic wood,

4 Aware of eyes that peep with a familiar gleam.

Like endless echoes that from somewhere far beyond,

Mingling, in one profound and cryptic whole unite,

Vast as the twin immensities at night and light,

8 So do all colors, sounds, and perfumes correspond.

Perfumes there are as fresh as children's bodies, springs

Of fragrance sweet as oboes, green and full of peace

As prairies. And there are others, proud, corrupt, intense, 
12 Having the all-pervasiveness of infinite things,

Like burning spice or resin, musk or ambergris,

That sing the raptures of the spirit and the sense.

\section{Jacques Leclerq (1958)}

\section{Correspondences}

In Nature's temple, living pillars rise,

Speaking sometimes in words of abstruse sense ;

Man walks through woods of symbols, dark and dense,

4 Which gaze at him with fond familiar eyes.

Like distant echoes blent in the beyond

In unity, in a deep darksome way,

Vast as black night and vast as splendent day,

8 Perfumes and sounds and colors correspond.

Some scents are cool as children's flesh is cool,

Sweet as are oboes, green as meadowlands,

And others rich, corrupt, triumphant, full,

12 Expanding as infinity expands :

Benzoin or musk or amber that incenses,

Hymning the ecstasy of soul and senses.

\section{E C.F. MacIntyre (1947)}

Nature is a temple of living pillars

where often words emerge, confused and dim; and man goes through this forest, with familiar

4 eyes of symbols always watching him.

Like prolonged echoes mingling far away

in a unity tenebrous and profound,

vast as the night and as the limpid day,

8 perfumes, sounds, and colors correspond.

There are perfumes as cool as children's flesh,

Sweet as oboes, as meadows green and fresh;

- others, triumphant and corrupt and rich,

12 with power to fill the infinite expanses,

like amber, incense, musk, and benzoin, which

sing the transports of the soul and senses.

Notes

1. See Prawer 1973 : 74-75 for a historical discussion and the two quotations. Prawer in turn refers us to Huyssen $1969: 18,51,188$. For a more recent restatement of the same dichotomy, see Raffel (1971:9), who is also a practising translator :

like Alice, his [the literalist's] translation is intended to take one through the looking glass back into the original poem - or as close to the original as may be possible, given linguistic, cultural, and personal differences. The "free" translator assumes that his job is to take the poem out through the mirror, bring it from its original environment into the world of those who read whatever language he is translating into.

For Raffel, "Both parties believe that" "the translator's task is to recreate... a pre-existing poetic experience" - the first emphasizing "the idioms and constructions, the sounds and the rhythms" of the source 
language, the latter those of the target language. But these "differences are not matters of theory". It may be argued that having two dichotomies rather than one permits us to speak more clearly of the things that Goethe, Schleiermacher, and Raffel are talking about. When Raffel credits both the parties with an attempt to recreate a pre-existing experience, he is crediting them with graduating from the naive schema (2) to the more sophisticated schemata (3) and (4).

2. The term "imitation" has now been revived in more or less Dryden's sense by the American Poet Robert Lowell (in introducing his 1961 collection of Imitations he says, "I have tried...to do what my authors might have done if they were writing their poems now and in America"). Cf. Raffel $1971: 12-13 \mathrm{fn}$. Dryden's middle way satisfies both historicist and Romanticist scruples.

3. Consider Pannwitz's telling indictment of contemporary translators from other languages to German (quoted by Benjamin 1923 (1973:80-81) :

Our translators, even the best ones, proceed from a wrong premise. They want to turn Hindi, Greek, English into German instead of turning German into Hindi, Greek, English. Our translators have a far greater reverence for the usage of their own language than for the spirit of the foreign works. ...the translator ... must expand and deepen his language by means of the foreign language. It is not generally realized to what extent this is possible, ... how language differs from language almost the way dialect differs from dialect; however, this last is true only if one takes language seriously enough [and] go back to the primal elements of language itself and penetrate to the point where work, image and tone converge.

The Indian penchant for ' adapting' or ' imitating' Western literay works in Indian languages rather than 'translating' them appears to stem from a parallel "basic error".

As a contrast consider the part played by translations and imitations from the classics by Amyot, Ronsard and others in $16^{\text {th }}$ century French literature in enriching the French language, enlarging its dictional and metrical possibilities. (Tate 1972 : intervention by Serge Gavronsky, pp. 19-20.)

\section{REFERENCES}

BENJAMIN, Walter (1923) : "Die Aufgabe des Übersetzers". [The task of the translator : An Introduction to the Translation of Baudelaire's Tableaux parisiens.] Heidelberg. [In German.] Rptd. in his : Schriften, $2 \mathrm{v}$. Ed., Introd., Adorno, Theodor W., Frankfurt-am-Main : Suhrkampf Verlag, 1955. E.-tr. in his : Illuminations. Ed., introd., Aredt, Hannah. Tr. Zohn, Harry, New York, Harcourt, Brace and World, 1968 ; London, Cape, 1970 ; paperback, Fontana Books, London, Collins, 1973.

DRYDEN, John (1680) : Preface to his : Translations from Ovid's Epistles.

FORSTER, L. (1958) : Translation. In : Smith, A.H. (Ed.) : Aspects of Translation, London, Secker and Warburg.

GOETHE, J.W. von (1819) : Uebersetzungen. In : Noten und Abhandlungen zu bessern Verständnis des westöstlichen Divans, West-Östlicher Divan, Stuttgart.

HUYSSEN, A. (1969) : Die frühromantische Konzeption von Übersetzung und Aneignung, Zürich.

PANNWITZ, Rudolf : Die Krisis der europaïschen Kultur.

PRAWER, S.S. (1973) : Comparative Literary Studies : An Introduction, London, Duckworth. (Ch. 5 : Translation and Adaptation, pp. 74-98.)

RAFFEL, Burton (1971) : The Forked Tongue : A Study of the Translation Process, The Hague, Mouton. RAY, Punya Sloka (1962a) : The formation of prose, Word 18, pp. 313-325. Rptd. in his : Language Standardization, The Hague, Mouton, 1963, pp. $138 \mathrm{ff}$.

RAY, Punya Sloka (1962b) : "A Philosophy of Translation", Babel 8, pp. 182-188.

SCHLEIERMACHER, Friedrich (1813) : "Über die verchiedenen Methoden des Übersetzens", Rptd. in : Störig, Hans Joachin (Ed.) (1969), Das Problem des Übersetzens, Darmstadt.

TATE, Allen (1972) : The Translation of Poetry, Washington, D.C., The Gertrude Clarke Whittall Poetry and Literature Fund for the Library of Congress. Adress (1-11), discussion (12-38), notes (38).

* This is a revised and much augmented version of a seminar paper read at the Centre of French Studies, the School of Languages, Jawaharlal Nehru University, New Delhi, on 19 March 1977 during the tenure of a UGC National Fellowship. 